\title{
Pengaruh Manfaat Utilitarian dan Manfaat Hedonis serta Status Sosial terhadap Keputusan Perpindahan Merek dari Televisi Kabel ke Netflix (The Influence of Utilitarian Benefits and Hedonic Benefits and Social Status on Brand Switching Decisions from Cable Television to Netflix)
}

Asty Almaida $^{*}$, Dedi Hariadi Saputra ${ }^{2}$

Fakultas Ekonomi dan Bisnis, Departemen Manajemen, Universitas Hasanuddin, Makassar astyalmaida@unhas.ac.id

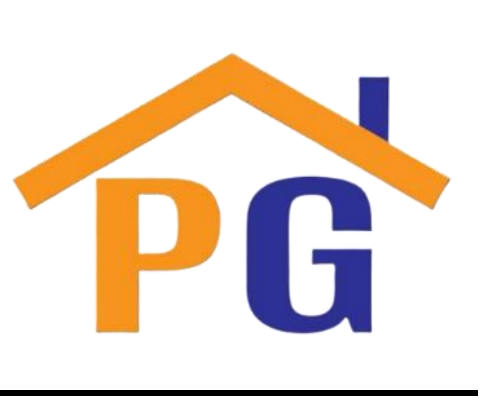

Riwayat Artikel

Diterima pada 18 Mei 2021

Direvisi pada 2 Juli 2021

Disetujui pada 2 Juli 2021

\begin{abstract}
Purpose: The purpose of this study is to determine the effect of utilitarian, hedonic, and social benefits on brand switching decisions from cable television to Netflix.

Research Methodology: The data for this study were gathered via questionnaires and a review of the literature. Purposive sampling was used to collect data from 92 respondents who were active undergraduate students at the Faculty of Economics and Business Unhas in the 2016-2018 academic year and used the Video on Demand (VoD) Netflix service. Multiple regression analysis, F test (simultaneous), and $\mathrm{T}$ test are used in the analysis (partial).

Results: The findings indicated that utilitarian benefits and social status had a positive and significant effect on brand switching decisions, whereas hedonic benefits had a negative and insignificant effect. Simultaneously, utilitarian, hedonic, and social benefits all have a positive and significant effect on brand switching decisions.

Keywords: Brand Switching Decisions, Hedonic Benefits Utilitarian Benefits, Social Status

How to cite: Almaida, A., \& Saputra, D, H. (2021). Pengaruh Manfaat Utilitarian dan Manfaat Hedonis serta Status Sosial terhadap Keputusan Perpindahan Merek dari Televisi Kabel ke Netflix. Jurnal Bisnis dan Pemasaran Digital, 1(1), 49-59.
\end{abstract}

\section{Pendahuluan}

Kehadiran teknologi memungkinkan media informasi dan hiburan saat ini bukan hanya bersumber dari TV kabel saja, tetapi pula dapat diperoleh dari berbagai media, salah satunya adalah layanan Video on Demand (VoD) seperti Netflix, Hulu, Amazon Prime Video, HBO+, Disney+ dan masih banyak lagi. VoD adalah sistem yang memungkinkan pengguna untuk memilih tontonan video atau konten sesuai dengan keinginannya (Lestari, 2019). Lebih lanjut, VoD memungkinkan penggunanya untuk melakukan proses streaming, progressive downloading ataupun download. Sistem ini juga memungkinkan para pengguna untuk melakukan kendali penuh pada layanan tersebut, seperti pause, fastforward, fastrewind, slowforward dan lain-lain. Lebih dari itu, beberapa plaftrom juga menyediakan layanan yang memungkinkan para pengguna untuk membagikan konten-konten yang ditonton di media sosial miliknya.

Stenovec (2015) menyatakan bahwa sejak tahun 2010 pengguna TV tradisional dan TV kabel berbayar mengalami penurunan hingga 10\%. Di lain sisi, terjadi peningkatan penggunaan layanan VoD seperti Netflix, Youtube maupun Hulu sekitar 30\% untuk pengguna yang melakukan streaming video. Zenith (2018) menyatakan bahwa seseorang kira-kira dapat menghabiskan sekitar 170,6 menit dengan internet dan 84 menit untuk menonton video, sebaliknya untuk televisi mengalami penurunan menjadi 170,3 menit dalam sehari. Lebih lanjut, data Puslibrang (2018) mencatat bahwa layanan VoD yang paling banyak diakses oleh masyarakat Indonesia usia di bawah 35 tahun salah satunya adalah Netflix. 
Netflix adalah layanan yang memungkinkan pengguna untuk menonton tayangan yang diinginkan kapan saja dan dimana saja serta hampir dapat diakses pada semua medium seperti TV, laptop, gawai dan lain-lain. Netflix merupakan pelopor munculnya layanan sewa film online yang berdiri sejak tahun 1997 dengan model bisnis awal berupa jasa sewa DVD dan rental melalui pengiriman. Tahun 2007 Netflix mengembangkan bisnisnya dengan memperkenalkan layanan streaming dan hingga 2016 Netflix telah beroperasi di lebih dari 160 negara. Di Indonesia sebagaimana paparan Katadata (2019) bahwa terjadi peningkatan jumlah pengguna VoD Netflix dari tahun 2017 hingga 2020. Di tahun 2017 pengguna Netflix berkisar 100 ribu pengguna dan di tahun 2020 telah mencapai 900 ribu pengguna. Manfaat yang ditawarkan Netflix seperti streaming, progressive downloading dan download dengan model kendali penuh menjadikan penggunanya terus meningkat dari tahun ke tahun.

Perpindahan merek menurut Toffer dan Imber dalam Setyo (2002) diartikan sebagai keputusan konsumen untuk membeli produk yang berbeda dari merek yang biasanya dikonsumsi. Perlu dipahami bahwa produk yang baik adalah yang mampu membuat konsumen merasa puas melalui manfaat yang dimilikinya. Semakin banyak manfaat yang ditawarkan oleh suatu produk maka semakin tinggi pula peluang konsumen untuk loyal terhadap produk tersebut. Mc Faden (1986) menyatakan bahwa kepuasan konsumen tersebut tidak hanya mencakup atribut fungsional, tetapi juga sosiopsikologis. Sementara itu Ailawadi (2001) menyatakan bahwa suatu produk memiliki dua manfaat, yaitu manfaat Utilitarian dan Hedonis. Semakin tinggi manfaat utilitarian dan hedonis yang dimiliki suatu produk, maka semakin tinggi pula kemungkinan konsumen untuk melakukan perpindahan produk (Mowen dan Minor, 2002).

Manfaat Utilitarian adalah manfaat-manfaat yang instrumental, fungsional dan kognitif (Hobrook, 1982). Nilai utilitarian menunjukkan keguataan produk atau layanan secara efisien, spesifik tugas dan ekonomis. Babin dkk (1994) mengemukakan bahwa keputusan manfaat utilitarian berdasar pada pertimbagan yang objektif fungsi atribut produk dan manfaat. Seorang konsumen yang mengonsumsi sebuah produk dengan mempertimbangkan manfaat utilitariannya akan menilai produk tersebut dari karakteristik objektifnya secara rasional (Setiadi, 2010).

Adapun manfaat hedonis adalah manfaat-manfaat yang non instrumental dan memberikan pengalaman emosi dan perasaan (Hirschman dan Holbrook, 1982). Babin dkk (1994) menyatakan bahwa suatu produk dikatakan memiliki manfaat hedonis ketika dapat memberikan rangsangan intrinsik, kesenangan dan penghargaan diri. Priansa (2017) mengemukakan bahwa motivasi belanja hedonis merupakan kebutuhan yang bersifat psikologis, seperti rasa puas, gengsi, emosi dan perasaan subjektif lainnya. Tuntutan sosial dan estetika seringkali menjadi penyebab munculnya kebutuhan ini, sebab pada dasarnya dalam mengambil keputusan dipengaruhi oleh faktor biologis dan emosional (Priansa, 2017). Terkadang seorang konsumen memutuskan untuk melakukan pembelian secara impulsif. Tidak ada proses tunggal yang digunakan oleh semua konsumen atau seorang konsumen dalam semua situasi produk (Koler dan Keller, 2012).

Selain kedua manfaat tersebut, status sosial juga dapat berpengaruh terhadap keputusan perpindahan merek (Faustine, 2015). Rao dkk (2000) mengemukakan bahwa teori identitas sosial juga menjelaskan bahwa perpindahan merek bukan hanya untuk memenuhi kebutuhan utilitas fungsional tetapi juga kebutuhan psikologis. Teori ini mengungkapkan bahwa seorang konsumen melakukan mobilitas sosial dari afiliasi kelompok sosialnya. Seseorang akan beralih ke merek lain untuk menggambarkan status sosialnya (Kotler, 2008). Kotler dan Amstrong (2001) juga menyebutkan bahwa terdapat tiga faktor sosial yang terlibat dalam keputusan konsumen, yaitu: kelompok referensi, keluarga dan status. Dengan demikian, dapat dipahami bahwa baik manfaat utilitarian, hedonis dan status sosial mampu mempengaruhi preferensi konsumsi konsumen terhadap suatu produk.

\section{Kajian Pustaka \\ Perilaku Konsumen}

Perilaku konsumen digunakan untuk menggambarkan tindakan konsumen akhir individu dan keluarga yang membeli produk atau layanan untuk penggunaan pribadi (Kotler dan Armstrong, 2012). Menurut Sciffman dan Kanu (2007), perilaku konsumen terkait erat dengan tindakan mencari, membeli, memanfaatkan, dan menghabiskan 
barang dan jasa yang mereka antisipasi akan memenuhi kebutuhan mereka. Banyak faktor yang dapat mempengaruhi perilaku konsumen. Menurut Kotler dan Armstrong (2012), ada empat faktor yang mempengaruhi perilaku konsumen: (1) Budaya (termasuk budaya dan nilai-nilai yang dianut masyarakat, subkultur yang membentuk segmen pasar, dan kelas sosial), (2) Sosial (termasuk referensi, keluarga, dan peran dan status), dan (3) Faktor Pribadi (termasuk usia dan tahap siklus hidup, pekerjaan, situasi ekonomi, gaya hidup, dan kepribadian) (seperti motivasi, persepsi, pembelajaran, keyakinan dan sikap). Selain itu, perilaku konsumen tidak dapat dipisahkan dari tingkat pemahaman produk mereka. Pengetahuan konsumen dapat didefinisikan sebagai kumpulan pengalaman dan informasi seseorang mengenai produk atau layanan tertentu (Mowen dan Minor, 2002). Pengetahuan dapat meliputi produk, merek, atribut, fitur produk, harga, dan kepercayaan mengenai produk tersebut (Engel dkk., 1994).

\section{Manfaat Utilitarian, Manfaat Hedonis dan Status Sosial}

Hirschman dan Holbrook (1982) menyatakan bahwa Manfaat Utilitarian adalah manfaat-manfaat yang bersifat instrumental, fungsional, dan kognitif. Babin dkk (1994) menambahkan bahwa manfaat utilitarian berdasar pada pertimbangan objektif, fungsi atribut produk atau manfaat. Dalam mengidentifikasi manfaat utilitarian Schifman dan Kanuk (2004) menyatakan bahwa terdapat beberapa indikator yang dapat diperhatikan, yaitu: (1) Cost Saving, dimana merupakan persepsi konsumen terhadap penghematan biaya yang dikorbankan untuk memperoleh sebuah produk, baik dari segi harga, waktu maupun usaha untuk memperoleh produk tersebut, (2) Convenience, yaitu kemudahan dalam memperoleh produk, meliputi penghematan waktu dan usaha yang diperlukan untuk memperoleh produk tersebut, (3) Affordability, yaitu sejauh mana pelanggan di pasar sasaran secara ekonomi dan psikologi bersedia membayar harga produk, (4) Multipe Benefits, yaitu sejumlah manfaat yang dimiliki oleh sebuah produk selain manfaat aslinya. Sementara Manfaat Hedonis merupakan manfaat yang bersifat non instrumental, memberikan pengalaman, emosi dan perasaan (Hirscman dan Holbrook, 1982). Sedangkan menurut Babin dkk (1994), suatu manfaat dapat digolongkan kepada manfaat hedonis manakala manfaat tersebut memberikan rangsangan intrinsik, kesenangan, dan penghargaan diri. Fallefi (2018) berpendapat bahwa manfaat hedonis dapat dikenali melalui beberapa indikator, yaitu: (1) Desain produk, (2) Iklan dan promosi, dan (3) Kebiasaan mengonsumsi.

Adapun Status Sosial dapat diartikan sebagaimana kelas sosial, yaitu pembagian masyarakat ke dalam kelas-kelas yang berbeda atau strata yang berbeda (Sumarwan, 2010). Soekanto (2012) menambahkan bahwa statusi sosial dapat disebut pula kedudukan sosial, yaitu tempat seseorang secara umum dalam masyarakat terkait hubungannya dengan orang lain, dalam arti lingkungan pergaulannya, prestisenya, dan hak-hak serta kewajibannya. Status sosial dalam masyarakat dapat mempengaruhi perilaku pembelian seseorang terhadap suatu produk atau jasa. Selain itu peran dan status dalam masyarakat dapat pula mengubah pemikiran seseorang dan keputusan mereka dalam melakukan perpindahan merek (Kotler, 2008). Faustine (2013) mengemukakan bahwa status sosial dapat diukur melalui tiga indikator, yaitu: (1) Idola, (2) Keluarga dan kerabat, dan (3) Kelas atas.

\section{Perpindahan Merek (Brand Switching)}

Srinivasan (1996) menyatakan bahwa Perpindahan Merek merupakan fenomena kompleks yang dipengaruhi oleh faktor-faktor, keperilakuan, persaingan, dan waktu. Ganes dkk dalam Khatrin (2006) mendefinisikan perpindahan merek sebagai perilaku konsumen yang mencerminkan pergantian dari produk yang biasa dikonsumsi dengan produk merek lain. Assael (1995) mengemukakan bahwa perpindahan merek terjadi pada produk-produk dengan karakteristik keterlibatan pembelian yang rendah. Perpindahan merek dapat ditandai dengan adanya perbedaan antar merek dimana perbedaan tersebut tampak sangat signifikan. Perpindahan merek juga dapat diamati pada rendahnya keterlibatan konsumen. Pada kondisi ini konsumen tidak melalui tahap-tahap keyakinan, sikap dan perilaku yang normal terhadap produk atau jasa tersebut. Lebih lanjut, konsumen tidak secara ekstensif mencari informasi mengenai merek tersebut, melainkan hanya menerima informasi secara pasif. Dengan demikian konsumen tidak membentuk keyakinan brand, tetapi memiliki suatu merek karena merek tersebut hanya dirasa akrab.

Terdapat serangkaian faktor yang dapat mempengaruhi konsumen dalam melakukan perpindahan merek, yaitu: (1) Harga produk, dimana memiliki hubungan terbalik dan negatif terhadap permintaan terhadap suatu produk atau jasa dalam keadaan normal, artinya semakin tinggi harga maka semakin rendah permintaan. Kendati demikian, dalam beberapa kondisi dapat ditemukan produk yang memiliki prestise tertentu justru berhubungan searah dan positif, (2) Kualitas produk, yaitu senjata potensial untuk mengalahkan pesaing melalui kemampuan dalam menunjukkan berbagai fungsi yang ditawarkannya, termasuk di dalamnya ketahanan, keandalan, ketepatan dan kemudahan dalam 
penggunaan (Amstrong, 2008), (3) Promosi produk, yaitu aktivitas untuk mengkomunikasikan keunggulan produk dan membujuk pelanggan agar membeli produk tersebut (Kotler dan Amstrong, 2014), dan (4) Persediaan produk, dimana berkaitan erat dengan kesediaan produsen untuk memenuhi permintaan yang masuk. Manajemen lebih suka menghendaki usaha-usaha untuk menghindari celah distribusi (out of stock) yang mungkin dapat mempercepat konsumen memutuskan untuk berpindah-pindah merek.

\section{Kerangka Pikir dan Hipotesis}

Berdasarkan kerangka pikir yang diproleh melalui hasil kajian literatur, maka hipotesis penulis dapat diuraikan sebagai berikut:

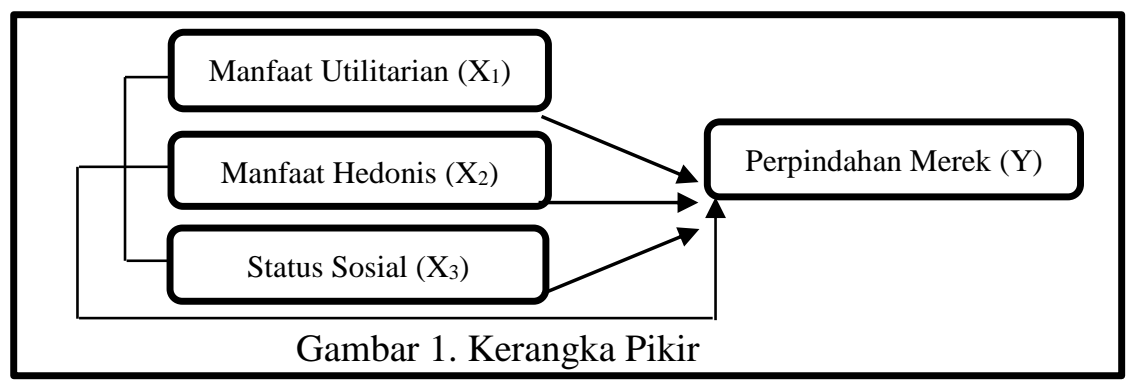

Hipotesis:

H1 : Diduga terdapat pengaruh Manfaat Utilitarian terhadap Keputusan Perpindahan Merek dari Televisi Kabel ke layanan Video on Demanding Netflix pada Mahasiswa FEB Unhas.

H2 : Diduga terdapat pengaruh Manfaat Hedonis terhadap Keputusan Perindahan Merek dari Televisi Kabel ke layanan Video on Demanding Netflix pada Mahasiswa FEB Unhas.

H3 : Diduga terdapat pengaruh Status Sosial terhadap Keputusan Perindahan Merek dari Televisi Kabel ke layanan Video on Demanding Netflix pada Mahasiswa FEB Unhas.

H4 : Diduga variabel Manfaat Utilitarian lebih dominan berpengaruh terhadap Keputusan Perindahan Merek dari Televisi Kabel ke layanan Video on Demanding Netflix pada Mahasiswa FEB Unhas.

\section{Metode Penelitian}

Penelitian ini menggunakan pendekatan kuantitatif dengan analisis linier berganda, yaitu dengan mengumpulkan data primer melalui metode penyebaran kuesioner di lingkungan Fakultas Ekonomi dan Bisnis Universitas Hasanuddin. Populasi dalam penelitian ini berjumlah 1.190 orang yang merupakan mahasiswa aktif Fakultas Ekonomi dan Bisnis Unhas jenjang Strata Satu jurusan Ilmu Ekonomi, Manajemen dan Akuntansi tahun angkatan 2016-218 yang terdaftar pada semester berjalan. Lebih lanjut, dalam menentukan sampel digunakan pendekatan purposive sampling dengan dua kriteria: (1) merupakan mahasiswa aktif jenjang Strata Satu Fakultas Ekonomi dan Bisnis Unhas tahun angkatan 2016-2018, dan (2) menggunakan layanan Video on Demand (VoD) Netflix. Dalam menentukan besarnya sampel, penelitian ini menggunakan rumus Slovin yang dihitung sebagai berikut:

$$
\begin{aligned}
& \mathrm{n}=\frac{\mathrm{N}}{1+\mathrm{N}(\mathrm{e})^{2}} \\
& \mathrm{n}=\frac{1.190}{1+1.190(0.10)^{2}} \\
& \mathrm{n}=92 \text { responden }
\end{aligned}
$$

Dalam Penelitian ini terdapat dua variabel, yaitu:

a. Variabel Independen (X). Variabel independen atau sering disebut sebagai variabel bebas, yang terbagi atas tiga yaitu Manfaat Utilitarian $\left(\mathrm{X}_{1}\right)$, Manfaat Hedonis $\left(\mathrm{X}_{2}\right)$, dan Status Sosial $\left(\mathrm{X}_{3}\right)$.

b. Variabel Dependen (Y). Variabel dependen sering disebut sebagai variabel terikat merupakan variabel yang menjadi pusat perhatian utama peneliti. Variabel dependen dalam penelitian ini adalah Perpindahan Merek (Y). 
Dalam melakukan pengujian hipotesis, penelitian ini menggunakan serangkaian pengujian, yaitu:

a. Persamaan Regresi Linier Berganda. Analisis regresi linier berganda digunakan untuk mengukur pengaruh suatu perubahan peristiwa (variabel X) terhadap peristiwa lain (variabel Y). Regresi liner berganda dalam penelitian ini dikonversikan untuk menguji ada tidaknya pengaruh manfaat utilitarian, manfaat hedonis dan status sosial terhadap perpindahan merek. Analisis regresi linier berganda seperti yang dikutip dalam Sugiyono (2017), yaitu:

Keterangan:

$$
\mathrm{Y}=\mathrm{a}+\mathrm{b}_{1} \mathrm{X}_{1}+\mathrm{b}_{2} \mathrm{X}_{2}+\mathrm{b}_{3} \mathrm{X}_{3}+\mathrm{e}
$$

$\mathrm{Y}=$ Variabel Dependen, yaitu Perpindahan Merek

$\mathrm{b}_{1} \ldots \mathrm{b}_{3}=$ Koefisien regresi

$\mathrm{X} 1 \quad=$ Variabel Independen, yaitu Manfaat Utilitarian

$\mathrm{X} 2=$ Variabel Independen, yaitu Manfaat Hedonis

X3 = Variabel Independen, yaitu Manfaat Sosial

e $\quad=$ Standar error

a. Koefisien Determinasi $\left(\mathrm{R}^{2}\right)$, yaitu menunjukkan sejauh mana kontribusi variabel independen terhadap variabel dependen dengan memeriksa ukuran keseluruhan koefisien determinasi $\left(\mathrm{R}^{2}\right)$. Nilai koefisien determinasi untuk variabel bebas lebih dari dua digunakan Adjusted R Square.

b. Statistik Deskriptif, yaitu statistik yang digunakan untuk mengevaluasi data dengan cara merangkum atau menggambarkan fakta apa adanya, tanpa tujuan menarik kesimpulan yang berlaku untuk generalisasi yang luas (Sugiyono, 2017).

c. Uji F (Simultan/Serempak), yaitu digunakan untuk mengetahui pengaruh semua faktor independen terhadap variabel dependen (variabel terikat). Jika sig. > $(0,10)$, H0 diterima dan H1 ditolak, sedangkan sig. (0.10), H0 ditolak dan H1 diterima.

d. Uji t (Uji Parsial), yaitu uji yang digunakan untuk mengevaluasi signifikansi pengaruh masingmasing variabel bebas terhadap variabel terikat secara terpisah, dengan asumsi variabel terikat konstan. Ini dapat dicapai dengan memeriksa tabel koefisien di kolom sig. (signifikansi) dihitung dari data uji menggunakan program SPSS versi 24. Menurut Santoso (2002), berikut ini adalah dasar pengambilan keputusan pengujian hipotesis: Jika nilai signifikansi lebih kecil dari taraf signifikan yang digunakan $(\alpha)$, maka dapat disimpulkan bahwa variabel independen mempunyai pengaruh yang signifikan terhadap variabel dependen. Jika nilai signifikansi melebihi ambang signifikansi yang digunakan ( $\alpha$ ), maka dapat disimpulkan bahwa variabel independen tidak memiliki pengaruh yang berarti terhadap variabel dependen.

\section{Hasil}

\section{Karakteristik Sampel}

Responden dalam penelitian ini adalah Mahasiswa Aktif Fakultas Ekonomi dan Bisnis Universitas Hasanuddin Tahun Angkatan 2016-2018 yang pernah atau sedang berlangganan TV kabel dan Netflix. Karakteristik responden yang dimasukkan dalam penelitian ini mencakup: jenis kelamin, departemen, tahun angkatan dan usia responden. Responden dalam penelitian ini diidentifikasikan menurut jenis kelamin dapat dilihat melalui tabel berikut:

Tabel 1. Karakteristik Responden Berdasarkan Jenis Kelamin

\begin{tabular}{ccc}
\hline Jenis Kelamin Responden & Frekuensi (Orang) & Persentase (\%) \\
\hline Laki-laki & 32 & 34.79 \\
Perempuan & 60 & 65.21 \\
\hline Jumlah & 92 & 100 \\
\hline
\end{tabular}


Karakteristik responden menurut departemen dapat diamati pada tabel berikut:

Tabel 2. Karakteristik Responden Berdasarkan Departemen

\begin{tabular}{ccc}
\hline Departemen & Frekuensi (Orang) & Persentase (\%) \\
\hline Ilmu Ekonomi & 9 & 9.79 \\
Manajemen & 71 & 77.17 \\
Akuntansi & 12 & 13.04 \\
\hline Jumlah & 92 & 100 \\
\hline
\end{tabular}

Karakteristik responden menurut tahun angkatan dapat diamati pada tabel berikut:

Tabel 3. Karakterstik Responden Berdasarkan Tahun Angkatan

\begin{tabular}{ccc}
\hline Tahun Angkatan & Frekuensi (Orang) & Persentase (\%) \\
\hline 2016 & 75 & 81.52 \\
2017 & 8 & 8.69 \\
2018 & 9 & 9.79 \\
\hline Jumlah & 92 & 100 \\
\hline
\end{tabular}

\section{Uji Validitas dan Reliabilitas}

Uji Validitas merupakan pengujian yang dilakukan untuk mengetahui valid atau sahnya variabel penelitian. Validitas ditentukan dengan menguji korelasi antara item pernyataan dan item total (skor total). Jika nilai korelasi total item yang disesuaikan lebih dari 0,30, itu dianggap sah.

Tabel 4. Hasil Pengujian Validitas

\begin{tabular}{|c|c|c|c|c|}
\hline Variabel & Pernyataan & $\begin{array}{c}\text { Corrected } \\
\text { item total } \\
\text { correlation }\end{array}$ & $\mathbf{r}_{\text {standar }}$ & Kesimpulan \\
\hline \multirow{7}{*}{$\begin{array}{l}\text { Manfaat Utilitarian } \\
\left(\mathbf{X}_{1}\right)\end{array}$} & 1 & 0.747 & 0.296 & Valid \\
\hline & 2 & 0.770 & 0.296 & Valid \\
\hline & 3 & 0.710 & 0.296 & Valid \\
\hline & 4 & 0.665 & 0.296 & Valid \\
\hline & 5 & 0.710 & 0.296 & Valid \\
\hline & 6 & 0.773 & 0.296 & Valid \\
\hline & 7 & 0.754 & 0.296 & Valid \\
\hline \multirow{7}{*}{$\begin{array}{l}\text { Manfaat Hedonis } \\
\left(\mathrm{X}_{2}\right)\end{array}$} & 8 & 0.619 & 0.296 & Valid \\
\hline & 9 & 0.852 & 0.296 & Valid \\
\hline & 10 & 0.853 & 0.296 & Valid \\
\hline & 11 & 0.871 & 0.296 & Valid \\
\hline & 12 & 0.833 & 0.296 & Valid \\
\hline & 13 & 0.861 & 0.296 & Valid \\
\hline & 14 & 0.759 & 0.296 & Valid \\
\hline \multirow{6}{*}{$\begin{array}{l}\text { Status Sosial } \\
\left(\mathbf{X}_{3}\right)\end{array}$} & 15 & 0.692 & 0.296 & Valid \\
\hline & 16 & 0.762 & 0.296 & Valid \\
\hline & 17 & 0.776 & 0.296 & Valid \\
\hline & 18 & 0.846 & 0.296 & Valid \\
\hline & 19 & 0.839 & 0.296 & Valid \\
\hline & 20 & 0.806 & 0.296 & Valid \\
\hline Keputusan & 21 & 0.668 & 0.296 & Valid \\
\hline Perpindahan Merek & 22 & 0.827 & 0.296 & Valid \\
\hline
\end{tabular}




\begin{tabular}{lllll}
\hline (Y) & 23 & 0.823 & 0.296 & Valid \\
& 24 & 0.768 & 0.296 & Valid \\
& 25 & 0.695 & 0.296 & Valid \\
& 26 & 0.647 & 0.296 & Valid \\
\hline
\end{tabular}

Uji reliabilitas digunakan untuk mengetahui reliabilitas suatu kuesioner yang berfungsi sebagai indikasi suatu variabel. Dalam penelitian ini reliabilitas ditentukan melalui perbandingan nilai Alpha dengan standar menggunakan perhitungan koefisien Cronbach Alpha. Suatu variabel dikatakan reliabel jika nilai Cronbach Alphanya lebih besar dari 0,60.

Tabel 5. Hasil Pengujian Reliabilitas

\begin{tabular}{ccccc}
\hline No. & Variabel & $\begin{array}{c}\text { Cronbach's Alpha Based } \\
\text { on Standardized Items }\end{array}$ & $\begin{array}{c}\text { Standar } \\
\text { Reliabilitas }\end{array}$ & Kesimpulan \\
\hline 1 & $\mathrm{X}_{1}$ & 0.794 & 0.60 & Reliabel \\
2 & $\mathrm{X}_{2}$ & 0.781 & 0.60 & Reliabel \\
3 & $\mathrm{X}_{3}$ & 0.795 & 0.60 & Reliabel \\
4 & $\mathrm{Y}$ & 0.786 & 0.60 & Reliabel \\
\hline
\end{tabular}

Berdasarkan Tabel 4 dan Tabel 5 nampak bahwa semua variabel memiliki nilai corrected item total correlation > 0.30 dan nilai Cronbach's Alpha >0.60. Dengan demikian dapat disimpulkan bahwa semua pertanyaan dalam kuesioner adalah valid dan reliabel.

\section{Analisis Regresi Linear Berganda}

Tujuan dari analisis regresi adalah untuk mengetahui pengaruh satu variabel terhadap variabel lainnya. Analisis ini bertujuan untuk mengetahui pengaruh variabel independen terhadap variabel dependen yaitu pengaruh manfaat utilitatian, manfaat hedonis, dan status sosial terhadap keputusan perpindahan merek. Adapun hasil olah data dengan menggunakan SPSS versi 24 dapat dilihat pada Tabel 6 berikut:

Tabel 6. Hasil Regresi Linear Berganda

\begin{tabular}{ccccccc}
\hline \multicolumn{7}{c}{ Coefficients $^{\mathbf{a}}$} \\
\hline \multirow{2}{*}{ Model } & \multicolumn{2}{c}{$\begin{array}{c}\text { Unstandardized } \\
\text { Coefficients }\end{array}$} & $\begin{array}{c}\text { Standardized } \\
\text { Coefficients }\end{array}$ & \multirow{2}{*}{ T } & \multirow{2}{*}{ Sig. } \\
\cline { 3 - 5 } & $\mathbf{B}$ & Std. Error & Beta & & \\
\hline 1 & (Constant) & 2.275 & 2.083 & & 1.092 & .278 \\
& $\mathrm{X}_{1}$ & -0.084 & 0.124 & -0.076 & -0.675 & .502 \\
& $\mathrm{X}_{2}$ & 0.223 & 0.110 & 0.230 & 2.021 & .046 \\
& $\mathrm{X}_{3}$ & 0.683 & 0.115 & 0.646 & 5.949 & .000 \\
\hline
\end{tabular}

Hasil analisis regresi linear berganda pada Tabel 6 di atas menunjukkan bahwa manfaat utilitarian $\left(\mathrm{X}_{1}\right)$ dan status sosial $\left(\mathrm{X}_{3}\right)$ memiliki pengaruh signifikan terhadap keputusan perpindahan merek, sementara manfaat hedonis $\left(\mathrm{X}_{2}\right)$ memiliki pengaruh tidak signifikan terhadap keputusan perpindahan merek. Dari Tabel 6 diperoleh persamaan model regresi sebagai berikut:

$$
Y=2.275-0.084 X_{1}+0.223 X_{2}+0.683 X_{3}
$$

Tabel 7 menunjukkan bahwa nilai $\mathrm{R}^{2}$ sebesar 0.582 (58.2\%), yang berarti bahwa besarnya pengaruh manfaat hedonis, manfaat utilitatian, status sosial adalah sebesar $58.2 \%$, sedangkan sisanya sebesar $41.8 \%$ dipengaruhi oleh variabel lain yang tidak dimasukkan dalam penelitian.

Tabel 7. Nilai R2 Hasil Regresi

\begin{tabular}{ccccc}
\hline & \multicolumn{3}{c}{ Model Summary } \\
\hline Model & R & R Square & Adjusted R Square & Std. Error of the Estimate \\
\hline 1 & $.772 \mathrm{a}$ & .596 & .582 & 3.207 \\
\hline
\end{tabular}


Dari Tabel 8 diperoleh nilai $\mathrm{F}$ adalah 43.303 dan Sig. 0.000. Lebih lanjut, dapat diamati bahwa nilai $F_{\text {hitung }}(43.303)>F_{\text {tabel }}(4.01)$ dan nilai Sig. $F(0.000)<0.10$. Dengan demikian dapat disimpulkan bahwa manfaat utilitarian, manfaat hedonis, dan status sosial secara simultan berpengaruh secara positif dan signifikan terhadap keputusan perpindahan merek.

Tabel 8. Hasil Uji F

ANOVA $^{\mathrm{a}}$

\begin{tabular}{llccccc}
\hline \multicolumn{2}{l}{ Model } & $\begin{array}{c}\text { Sum of } \\
\text { Squares }\end{array}$ & Df & $\begin{array}{c}\text { Mean } \\
\text { Square }\end{array}$ & F & Sig. \\
\hline \multirow{2}{*}{1} & Regression & 1335.941 & 3 & 445.314 & 43.303 & $.000^{\mathrm{b}}$ \\
& Residual & 904.961 & 88 & 10.284 & & \\
& Total & 2240.902 & 91 & & & \\
\hline
\end{tabular}

a. Dependent Variable: Y

b. Predictors: (Constant), $\mathrm{X}_{3}, \mathrm{X}_{2}, \mathrm{X}_{1}$

Tabel 9 menunjukkan informasi tentang pengaruh signifikansi setiap variabel bebas terhadap variabel berikat. Apabila nilai $t_{\text {hitung }}>t_{\text {tabel }}$, maka variabel bebas memberikan pengaruh terhadap variabel terikat. Begitupun jika tingkat signifikansinya $<0.10$, maka dapat dikatakan variabel bebas secara individu berpengaruh positif dan signifikan terhadap variabel terikat.

Tabel 9. Hasil Uji t

\begin{tabular}{clccccl}
\hline Kode & \multicolumn{1}{c}{ Variabel } & $\mathbf{B i}$ & $\mathbf{t}_{\text {hitung }}$ & $\mathbf{t}_{\text {tabel }}$ & Sig. & \multicolumn{1}{c}{ Kesimpulan } \\
\hline $\mathrm{X}_{1}$ & Manfaat Utilitarian & 0.223 & 2.021 & 1.66235 & 0.046 & Signifikan \\
$\mathrm{X}_{2}$ & Manfaat Hedonis & -0.084 & -0.675 & 1.66235 & 0.502 & Tidak Signifikan \\
$\mathrm{X}_{3}$ & Status Sosial & 0.683 & 5.949 & 1.66235 & 0.000 & Signifikan \\
\hline
\end{tabular}

Dari Tabel 9 diperoleh hasil uji $\mathrm{t}$ untuk setiap variabel. $\mathrm{H}_{1}$ diterima karena $\mathrm{t}_{\text {hitung }}(2.021)>\mathrm{t}_{\text {tabel }}(1.66235)$ dan Sig. $(0.046)<0.10$, dimana berarti secara parsial manfaat utilitarian memiliki hubungan yang positif dan signifikan (nilai $>0$ ) terhadap keputusan perpindahan merek. $\mathrm{H}_{2}$ ditolak karena $\mathrm{t}_{\text {hitung }}(-0.675)<\mathrm{t}_{\text {tabel }}$ (1.66235) dan Sig. (0.502) > 0.10, dimana berarti secara parsial manfaat hedonis memiliki hubungan yang negatif dan tidak signifikan terhadap keputusan perpindahan merek. $\mathrm{H}_{3}$ diterima karena $\mathrm{t}_{\text {hitung }}$ $(5.949)>t_{\text {tabel }}(1.66235)$ dan Sig. $(0.000)<0.10$ yang berarti bahwa secara parsial status sosial memiliki hubungan yang positif dan signifikan (nilai $>0$ ) terhadap keputusan perpindahan merek.

\section{Hasil dan Kesimpulan}

\section{Hasil}

Tujuan penelitian ini adalah untuk menguji pengaruh manfaat utilitarian, manfaat hedonis, dan status sosial terhadap keputusan mahasiswa FEB Unhas beralih merek dari televisi kabel ke Netflix. Hasil penelitian menunjukkan bahwa sementara manfaat utilitarian dan status sosial berpengaruh positif dan signifikan terhadap variabel terikat yaitu Keputusan Pengalihan Merek, variabel bebas Manfaat Hedonis berpengaruh negatif dan tidak signifikan terhadap variabel terikat yaitu Keputusan Pengalihan Merek.

Berikut uraian pembahasan pengaruh manfaat utilitarian, manfaat hedonis, dan status sosial terhadap keputusan pengalihan merek:

Pengaruh Manfaat Utilitarian terhadap Keputusan Perpindahan Merek

Berdasarkan hasil uji t pada Tabel 9 menunjukan nilai $\mathrm{t}_{\text {hitung }}(2.021)>$ nilai $\mathrm{t}_{\text {tabel }}(1.66235)$ dengan nilai signifikansi t sebesar 0.046 yang nilainya lebih kecil dari 0.10. Maka dengan demikian $\left(\mathrm{H}_{1}\right)$ diterima, yang artinya Manfaat Utilitarian berpengaruh positif dan signifikan terhadap Keputusan Perpindahan Merek dari Televisi Kabel ke Netflix pada Mahasiswa FEB Unhas. Temuan ini sejalan dengan teori yang dikemukakan oleh Hirschman dan Holbrook (1982) yang menyatakan bahwa seorang konsumen dalam memutuskan untuk mengonsumsi sebuah produk mempertimbangkan banyak hal, dimana salah satunya adalah manfaat utilitarian yang dimiliki oleh produk tersebut. 
Selain itu, temuan ini sejalan pula dengan penelitian yang dilakukan oleh Fallefi (2018) yang menyatakan bahwa manfaat utilitarian berpengaruh positif dan signifikan terhadap perpindahan merek dari smartphone lain ke Iphone.

\section{Pengaruh Manfaat Hedonis terhadap Keputusan Perpindahan Merek}

Berdasarkan hasil uji t pada Tabel 9 menunjukkan nilai thitung $(-0.675)<$ nilai $t_{\text {tabel }}(1.66235)$ dengan nilai signifikansi sebesar 0.502 yang nilainya lebih besar dari 0.10 . Maka dengan demikian hipotesis $\left(\mathrm{H}_{2}\right)$ ditolak, yang artinya Manfaat Hedonis berpengaruh negatif dan tidak signifikan terhadap Keputusan Perpindahan Merek dari Televisi Kabel ke Netflix pada Mahasiswa FEB Unhas. Temuan ini cukup menarik jika dibandingkan dengan pendapat umum yang menyatakan bahwa manfaat hedonis berpangaruh positif terhadap perpindahan merek. Kendati demikian, temuan ini sejalan dengan penelitian yang dilakukan oleh Cahyono (2019) yang memperlihatkan bahwa manfaat hedonis berpengaruh negatif terhadap impulsive buying. Penelitian ini menjelaskan pula bahwa untuk beberapa produk tertentu, konsumen hanya akan membeli sebuah produk yang memang telah direcanakan terlebih dahulu sebelumnya. Lebih lanjut, temuan ini sejalan pula dengan penelitian yang dilakukan oleh Rodriguez (2013) yang menyatakan bahwa manfaat hedonis memiliki pengaruh negatif terhadap penggunaan website dalam melakukan pembelian tiket pesawat.

\section{Pengaruh Status Sosial terhadap Keputusan Keputusan Perpindahan Merek}

Berdasarkan hasil uji t pada Tabel 9 menunjukkan bahwa nilai $t_{\text {hitung }}(5.949)>$ nilai $t_{\text {tabel }}(1.66235)$ dengan nilai signifikansi 0.000 yang nilainya lebih kecil dari 0.10 . Maka dengan demikian hipotesis $\left(\mathrm{H}_{3}\right)$ diterima, yang artinya bahwa Status Sosial berpengaruh positif dan signifikan terhadap Keputusan Perpindahan Merek dari Televisi Kabel ke Netflix pada Mahasiswa FEB Unhas. Hal ini cukup logis menimbang hanya konsumen yang memiliki kondisi ekonomi menengah ke atas dan selalu update dengan trend teknologi yang mampu mengenal dan menggunakan Netflix. Dalam penelitian ini pengaruh status sosial terhadap keputusan perpindahan merek dari Televisi Kabel ke Netflix dapat dibandingkan dengan beberapa teori dan hasil penelitian sebelumnya. Teori yang dikemukakan oleh Kotler dan Amstrong (2001) bahwa faktor sosial yang terlibat dalam keputusan perpindahan merek, yaitu keluarga, kelompok dan status sosial. Ketiga faktor sosial tersebut sangat berpengaruh terhadap pengambilan keputusan seorang konsumen dalam mengonsumsi suatu produk, baik berbentuk barang maupun jasa. Temuan ini sejalan dengan penelitian yang dilakukan oleh Faustine (2013) yang menyatakan bahwa status sosial berpengaruh positif dan signifikan terhadap perpindahan merek dari Blackberry ke Smartphone.

\section{Variabel Berpengaruh Dominan terhadap Keputusan Pembelian}

Berdasarkan hasil pengujian secara individu atau parsial masing-masing variabel independen terhadap variabel dependen dapat diamati bahwa variabel yang paling berpengaruh atau dominan terhadap keputusan perpindahan merek dari Televisi Kabel ke Netflix pada mahasiswa FEB Unhas adalah variabel Status Sosial. Dengan demikian hipotesis $\left(\mathrm{H}_{4}\right)$ ditolak. Hal ini dapat dibuktikan dengan melihat nilai thitung tetinggi dari variabel Status Sosial (5.949) yang lebih besar dari Manfaat Utilitarian (2.021).

\section{Kesimpulan}

Berdasarkan hasil penelitian yang telah dilakukan maka diperoleh kesimpulan sebagai berikut:

a. Manfaat Utilitarian, Manfaat Hedonis dan Status Sosial secara simultan memiliki hubungan yang positif dan signifikan terhadap Keputusan Perpindahan Merek.

b. Manfaat Utilitarian secara parsial memiliki hubungan yang positif dan signifikan terhadap Keputusan Perpindahan Merek.

c. Manfaat Hedonis secara parsial memiliki hubungan yang negatif dan tidak signifikan terhadap Keputusan Perpindahan Merek.

d. Status Sosial secara parsial memiliki hubungan yang positif dan signifikan terhadap Keputusan Perpindahan Merek.

e. Pengaruh Manfaat Utilitarian, Manfaat Hedonis dan Status Sosial berpengaruh terhadap Keputusan Perpindahan Merek yang ditunjukkan oleh pesamaan fungsi model regresi berganda dalam penelitian ini, yaitu sebesar 59.6\%. 


\section{Keterbatasan Penelitian dan Saran untuk Penelitian Selanjutnya}

Peneliti selanjutnya diharapkan dapat menyempurnakan penelitian ini dengan memasukkan elemen tambahan yang mempengaruhi keputusan pergantian merek untuk mencapai hasil yang lebih beragam. Selain itu, responden penelitian ini sebagian besar adalah mahasiswa manajemen dan angkatan 2016 yang tentunya masih terbatas dalam merepresentasikan keputusan mahasiswa FEB Unhas dalam melakukan perpindahan merek dari Televisi Kabel ke Netflix.

\section{Referensi}

Ailawadi, Kusum, Keren Gedenk, Scott A. Neslin. (2001). Pursuing The Value Conscious Consumer: Store Brand Versus National Brand Promotion. Journal of Marketing, 65, 71-89.

Assael, Henry. (1995). Consumer Behavior dan Marketing Action. PWS Kent Publishing Company, Boston.

Babin, Barry. J. William R. Darden, Mitch Griffin. (1994). Work and or Fun; Measuring Hedonic and Utilitarian Shopping Value. Journal of Consumer Research, 644-654.

Cahyono, Krido. (2019). Pengaruh Hedonic Value dan Utilitarian Value terhadap Impulse Buying di Media oleh Shopping Lifestyle pada Industri Kulit di Sidoarjo, 17(2).

Engel,J. F, Blackwell, R. P dan Miniard, P. W. (1994). Perilaku Konsumen. Jilid 1. Alih Bahasa: Budiyanto. Jakarta: Binarupa Aksara

Fallefi, R. Muhammad, Siregar, M. Ridha. (2018). Pengaruh Nilai Utlitarian dan Nilai Hedonis Terhadap Perpindahan Merek Dengan Kepuasan Konsumen Sebagai Pemoderasi (Studi Kasus Perpindahan Merek dari Smartphone Lain ke Iphone Pada Mahasiswa di Lingkungan Universitas Syiah Kuala). Aceh. Jurnal Ilmiah Mahasiswa Ekonomi Manajemen.

Faustine, Megan. (2013).The Impact of Variety Seeking, Social Status, Quality, and Advetisement Towards Brand Switching in Smartphone Product (A Case Study Of Blacberry User Thas Has Ever Changed Into Another Smartphone Product in Surabaya). Surabaya: iBuss Management.

Hirschman, Elizabeth C dan Morris E. Holbrook. (1982). Hedonic Consumption Emerging Concepts, Methods, and Propositions. Journal of Marketing, .46, 92-101.

Hernowo, Ridho Adhie. (2005). Pengaruh Manfaat Ekonomis dan Manfaat Hedonis Terhadap Keputusan Pembelian Pada Produk Nevada di Matahari. Surabaya. Universitas Airlangga

Hair Jr., J. F., Black, W. C., Babin, B. J., \& Anderson, R. E. (2014). Multivariate Data Analysis. England. Pearson Education Limited.

Hasan, Venny Ariesta. (2017). Analisis Faktor-Faktor Yang Mempengaruhi Willingness To Subscribe: Telaah Pada Layanan Video On Demand Netflix. Tangerang. Universitas Multimedia Nusantara Ultima Management.

Katadata. (2019). Berapa Pelanggan Streaming Netflix di Indonesia?. (Online). (http://databoks.katadata.co.id/datapublish/2019/08/13/berapa-pelanggan-streaming-netflix-diindonesia)

Khatrin., Karlina., Sherly. (2006). Analisis Faktor-Faktor yang Mempengaruhi Brand Switching Terhadap Bread Boutiques di Supermall Pakuwon Indah (SPI) Surabaya. Jurnal Universitas Kristen Petra. Surabaya.

Kotler, Phillip \& Gary Armstrong, G. (2001). Prinsip-prinsip Pemasaran. Jakarta: Erlangga

Kotler, Phillip. (2008). Manajemen Pemasaran. Jakarta: Indeks

Kotler, Philip \& Gary Armstrong. (2004). Principles of Marketing. $10^{\text {th }}$ Ed. New Jersey: Pearson Prentice Hall

Kotler, Phillip. (1997). Marketing Management: Analysis, Planning, Implementation and Control,7. New Jersey. Prentice Hall Int.

Kotler, Philip \& Gary Amstrong. (2014). Principles of Marketing 15th. New Jersey. Prentice Hall.

Kotler, P., \& Keller, K. L. (2007). Manajemen Pemasaran. Edisi 12 Jilid 1. Jakarta: Erlangga.

Lestari, Puji. (2019). Teknologi Sistem Telekomunikasi Tercanggih Dan Terkini Video On Demand. Purwokerto. Sekolah Tinggi Teknologi Telematika Telkom Purwokerto.

McFadden, Daniel. (1986). The Choice Theory Approach to Market Research. Marketing Science.

Michael, Mirabito Barbara L., Morgenstern. (2004). With a Foreword by Mitchell Kapor Focal Press is an imprint of Elsevier 200 Wheeler Road.UK. Elsevier Inc. 
Mowen, John C and Michael Minor. (2002). Perilaku Konsumen. Jilid 1 Edisi 5. Alih Bahasa Lina Salim. Jakarta. Erlangga.

Oriansa, Donni. (2017). Perilaku Konsumen Dalam Persaingan Bisnis Kontemporer. Bandung: Alfabeta

Prastya. (2013). Analisis Faktor-Faktor Yang Mempengaruhi Perpindahan Merek (Brand Switching) Kartu Indosat Im3. Skripsi tidak diterbitkan. Semarang. Universitas Diponegoro

Priansa, D. J. (2017). Perilaku Konsumen Dalam Bisnis Kontemporer. Bandung. CV Alfabeta

Puslitbang. (2019). Kajian Integrated Broadcast Broadband (IBB) di Indonesia. (Online). (https://www.google.com/search?q=Puslitbang+(2018)+Layanan+Video+on+Demand+(VoD)+y ang+paling+banyak+diakses+oleh+masyarakat+usia+dibawah+usia+35+tahun+antara+lain+iala $\mathrm{h}+$ Youtube $\% 2 \mathrm{C}+\mathrm{VIU} \% 2 \mathrm{C}+\mathrm{NETFLIX} \% 2 \mathrm{C}+$ Hotstar$\% 2 \mathrm{C}+$ dan+Amazon+Prime+Video.\&oq=)

Rao, Hayagreeva, Gerald F. Davis, and Andrew Ward. (2000). Embeddedness, Social Identity and Mobility: Why Firms Leave the NASDAQ and Join the New York Stock Exchange. Administrative Science Quarterly

Rodriguez, Tomas and Trujillo, Elena. (2013). Online Drivers of Customers Purchase of Website Airline Tickets. Journal of Transport Management. Spain

Sciffman, Leon G., Leslie Kanuk. (2010). Consumer Berhavior. Pearson Education

Setiadi, Nugroho J. (2010). Perilaku Konsumen. Jakarta: Kencana

Setyo, Ajie. (2002). Analisis Faktor-Faktor yang Mempengaruhi Konsumen dalam Melakukan Perpindahan Merek. Semarang. Tesis Universitas Dipenogoro Semarang.

Srinivasan, M. (1996). New Insight into Switching Customer Behavior. Journal of Marketing Research, 8(3). 27-28. University Microfilms International, a Bell and Howell Company. Michigan.

Sugiyono, P. (2017). Metode Penelitian Kombinasi. Bandung. CV Alfabeta

Soekanto, Soerjono. (2012). Sosiologi Suatu Pengantar. Jakarta. Rajawali Pers

Sumarwan, Ujang. (2011). Perilaku Konsumen Teori dan Penerannya dalam Pemasaran. Bogor. Ghalia Indonesia

SWA. (2019). Pengguna TV Streaming Mendekati Jumlah Pengguna TV Konvensional. (Online). (https://swa.co.id/swa/trends/pengguna-tv-streaming-mendekati-jumlah-pengguna-tvkonvensional)

Stenovec. (2019). We're About to Pass a Watershed Moment in The Decline of TV. (Online). (https://www.businessinsider.com/streamingwill-soon-pass-traditional-tv-20159? $\mathrm{IR}=\mathrm{T} \& \mathrm{r}=\mathrm{US} \& \mathrm{IR}=\mathrm{T}$ )

Statista. (2019). Video-On-Demand. (Online). (https://www.statista. com/outlook/201/100/video-ondemand/worldwide

VOX. (2019). People consumed more media than ever last year - but growth is slowing. (Online). (https://www.vox.com/2017/5/30/15712660/media-consumption-zenith-mobile-internet-tv 